\title{
EDUCATING FOR ACTIVE CITIZENSHIP AND SUSTAINABLE DEVELOPMENT
}

\begin{abstract}
In this essay the question of how to reconcile active citizenship and sustainable development will be addressed. In particular, it is a question of developing in the first part of the article a reflection on the education of the citizen, in the second part the necessary conditions for the school to be able to contribute to the formation of the citizen will be addressed and finally the third part will be dedicated to demonstrating how and why the citizen education must also be carried out outside of school, in social life, in acting for sustainable development.
\end{abstract}

KEYWORDS: educating; citizenship; sustainable development

\section{EDUCATING FOR CITIZENSHIP}

In an educational landscape that has become over the past decade complex, families ask the school to broaden its horizons to a multicultural coexistence, trying to hold together for all the children who live in it learning and being able to stay in the world. What can be done to revive the sense of citizenship and the rules of civil coexistence in contemporary generations? Surely one cannot ignore the awareness that the founding values of a civil society must be taught from an early age: it is necessary, therefore, to intervene already from the school desks, starting from the kindergarten. The latter presented by the new Guidelines as a response to children's right to education and care with the aim of promoting the development of identity, autonomy, competence and starting citizenship. (Indicazioni nazionali e nuovi scenari, 2018, pp. 5-7). 
The concept of citizenship can be defined by considering the different levels: the citizenship as belonging to the city and to the local community, in this case the exercise of citizenship gives the possibility to fully develop one's role, the responsibilities of member of the city and, in the same time, the opportunity to benefit from the rights that this membership recognizes. The citizenship includes participation in intermediate communities, especially regional ones, even if the territorial aspect is not to be considered. An active participation in associations and movements that express themselves in collective life and that contribute to weaving the social whole, allows the exercise of a form of citizenship. There is a precise meaning of citizenship: that which defines it as belonging to a historical community whose freedom and responsibility are exercised through nationality. True citizenship consists in seeking harmony between the different circles working to overcome the inevitable contradictions and puts each circle in a position to relate to others instead of excluding them (Baudrillard, 1991).

The person, in his full sense, would be the active individual who engages in a work of harmonization of the different circuits of citizenship. Being a citizen and acquiring citizenship requires a difficult path that we will call education, as education promotes entry into a culture. Education does not only entail the conquest of courtesy and is not even a simple socialization, but it is entry into a human world that precedes me and that is available in the form of cultural heritage. On the other hand, education is not even the monopoly of the school since there are three large educational agencies: the family that favors entry into an original culture, the school that, through school culture, allows taking part in the common culture, and finally a third place that is neither the family nor the school, but which is nevertheless indispensable. Neither family nor school is sufficient to ensure a complete education (Cadei, Deluigi, Pourtois, 2016).

Our reflection on the school has lost a lot when it did not take into consideration the strong and very ancient bond that links education and culture. It is therefore necessary to speak of an education of the citizen because one becomes such on the basis of precise conditions of a cultural nature: the individual becomes a citizen passing through culture. 
The school, in the education of the citizen, cannot do everything, but it has a role to play. I try to think, contrary to what is widely believed, that it is not a desirable task to contrast culture and school, but that the purpose of the school has a prevalent cultural character. The education of the citizen has an important part in this school culture. Is it then possible to examine what this culture of the citizen should produce? What does an individual need to face his responsibilities as a citizen? A necessary condition is an authentic awareness of the political fact. In the first place, one cannot be considered a citizen without the ability to assume and live belonging to a collective subject. It is not difficult to recognize that the individual who is totally turned back on himself, on his own private, self-referential life, devoid of any feeling of belonging can not live citizenship (Mortari, 2004).

The education of the citizen must take on a job on belonging and this implies an ability to reflect on the different dimensions of citizenship. The various dimensions of citizenship recall a plurality of belonging that must be thought not as exclusive to one another, but as a joint: democracy would not know how to exist without referring to a single society, while the individual becomes authentically a citizen when he considers his own subjectivity as referring to a collective subject which, in modernity, cannot be anything other than a historical subject. Educating the citizen, in the school context, means helping him to build himself as an active subject of belonging to a collective historical subject. Another fundamental aspect for an education for active citizenship involves the possibility of schools to train the child to an ability to think about the action to such an extent that, for his conscience, it becomes a real need. It is true that the school is not the direct place for a political commitment, but it is at least the place where one can raise the consciousness towards the obligation of a political commitment. However, it is not the only place where education is developed, but the third place, that which is not identified either with the family or with the school, has an important function. The different disciplines can contribute favorably to laying the foundations for the construction of citizenship, for example the teaching of history concerns all aspects of citizen education. History, in the first place, intervenes, in an important way, in the construction of a common memory, without which the identity and unity of a society fail. Memory is not identical to history, as it offers those references to 
reality, thanks to which a relationship will be established with the becoming. Undoubtedly this relationship of the person with a collective past allows her to better understand her place in becoming and helps her to understand that the present will not last forever and that he has a common future to build. Today's citizens play an important role in building a better and more democratic society; developing the skills and attitudes of active citizenship is essential for improving the society in which we live.

\section{GLOBAL CITIZENSHIP AS A REGULATORY IDEA}

The school of the twenty-first century is called to educate to coexistence with others by enhancing civil, civic and religious education. The wide theme of education (citizenship, civil cohabitation, health, affectivity, etc.) finds space in national indications, but not always in school organization, not benefiting from an explicitly dedicated number of hours, nor from a responsible teacher. Every day the press refers us to news of bullying, violence, intolerance towards diversity, acts of hooliganism and vandalism, demotivation to learn, de-schooling, all behaviors that make it difficult to build a peaceful classroom environment necessary for the cultural growth of children. This is a real educational emergency, which should be addressed by returning the school-family alliance that in recent years has been greatly weakened and has become a conflict (Zizioli, 2018).

In the Unesco Report of the International Commission on Education for the XXI Century (1996) it was stated that "the central goal of education is the realization of the individual as a social being" and four priority objectives were proposed: 1) learning to know; 2 ) learning to be (critical thinking skills, autonomy and responsibility); 3 ) learn to do; 4) learn to live with others.

In the Recommendation of the European Parliament and of the Council on key competences for lifelong learning (2006) eight key competences are outlined, including social and civic ones, which "include personal, interpersonal and intercultural competences and concern all forms of behavior that allow people to participate effectively and constructively in social and work life by "demonstrating" the ability to communicate constructively in different environments, to show tolerance, to express and to understand different points of view, to negotiate with the ability to create trust and to be 
in agreement with others, sense of responsibility, as well as understanding and respect for shared values.

In May 2010 all EU Member States adopted the Council of Europe Charter on Education for Democratic Citizenship and Human Rights Education, which, based on a concept of universal citizenship, proposes global education , including development education, human rights, sustainable development, peace, conflict prevention and inter-culture, pursued through both formal and in-school learning, both non-formal and informal.

As stated in the Report by Eurydice, published in 2012, "in the most important political documents that have shaped European cooperation over the last decade and which will influence what will happen between now and 2020, the importance of promoting a active citizenship and this, consequently, has become one of the main objectives of education systems throughout Europe "(Eurydice Report, 2012).

In the Report, citizenship education refers to aspects of school education aimed at preparing students to become active citizens, guaranteeing them the knowledge, skills and abilities necessary to contribute to the development and well-being of the society in which they live.

Citizenship education confirms and teaches those values that a society considers important, training the citizen to respect them and make them their own to become, in respect of coexistence and solidarity, a better adult. Despite the consensus on the importance of this teaching, education for citizenship in schools cannot be said to be "fully developed", but encounters various difficulties and obstacles. This happens both when a maximalist version of the objectives of this discipline is proposed, according to which the destinies of a society would be entrusted almost exclusively to the influence of the school, both when it is limited to a more moderate vision, which entrusts only the education to education the task of literacy of the new generations in the rights / duties of citizenship is therefore necessary to encourage a humanist culture that can favor inclusion and citizenship policies and not hinder the human development process that revolves around the concept of capabilities understood as the capacity of all individuals to be able to translate into access to rights and thus use resources in all their fullness (Nussbaum, 2011-Baldacci, 2014). 
The classic definition of citizenship, which we have examined so far, appears today insufficient, since it mainly highlights the aspect of the relationship between the citizen and the national state. In reality, today's citizenship is today profoundly transformed, in a world where diversity is reality and where pluralism derived from the coexistence of linguistic-cultural minorities and, above all, immigration dominates. This heterogeneity, created by historical and political circumstances, has undermined the relationship between traditional forms of the political system and particularistic demands. The dilemma of including immigrants or minorities, especially at the level of political and socio-cultural rights, determines the need to define the new identity of the modern nation-state. The extension of citizenship, in terms of civil, political, social and now also cultural rights, presents itself as a central topic of the conflict of modernity. From many sides, we are now discussing the limits of citizenship: within or beyond the borders of the national state? Today we increasingly talk about global citizenship, with the very rapid changes from an economic, technological, ecological and political point of view, a broad vision of the local community of belonging is becoming more and more important. Globalization is presented as a set of material and symbolic processes at the same time. Although the myth of globalization would tend inexorably towards the unification of the world, we are actually facing a "ubiquitous patchwork": global processes do not tend naturally towards unity or uniformity, but on the contrary, if left to themselves, they help to remove the ideal of community, producing strong imbalances and inequalities. Hence it is important to remember the concept of sustainable development to corroborate education for global citizenship in an intercultural perspective (Pinto Minerva, 2008 - Zoletto, 2017 - Fiorucci, 2014).

The relationship between the global and the local, very complex, creates new rights and duties on a planetary level, which do not necessarily coincide with those deriving from national loyalty. Even modern individualism, typical of Western societies, pushes us to review the idea of citizenship in the light of the pluralism of ways of life, of thinking, of believing. If, on the juridical-political level, the road to global citizenship questions the will of individuals and states, then it is necessary to ask what the role of education might be. The pedagogical reflection can put itself at the service of an ideal 
of progressive widening of the sense of belonging, but avoiding any kind of cosmopolitan utopia. In this sense we can speak of "global citizenship", but under certain conditions. The risk felt by the adversaries of this idea of "loss of boundaries" of citizenship education that makes it even more elusive is real. The experience of civic education in schools in all countries confirms, in fact, that this field of knowledge requires a serious and rigorous definition. Is the extension to the global, one wonders, contributing to making education for citizenship even more evanescent? The challenge of thinking about global citizenship can be met on a pedagogical level, starting from the awareness of belonging to an increasingly complex and globalized world, in which phenomena and events have close connections and interdependencies. It is about perceiving the world as a system of which men and women are citizens, a source of rights to be enjoyed and duties to be respected. From a cultural and pedagogical point of view, global citizenship, as a regulative idea, represents a possible challenge. The problem, from an educational point of view, must be placed on the level of a belonging that does not appear disincarnate and devoid of cultural and existential references. However, as some fear, this enlargement of perspective does not mean the loss of the national position and the indispensable state reference. Instead it should be thought of as a multiplication of belonging, which extends to the global without canceling the local ones. In this scenario, education will have to contribute to forming free people to decide which priority to give, from time to time, to their identity (Reimers, Barzanò, Fisichella, Lissoni, 2017).

In an increasingly multi-ethnic and multicultural society, the problem of identity leads to the weakening of the social bond, for this a curriculum project must include traditional elements of citizenship education: knowledge of civic culture, transmission and communication of the national language, acceptance of the constitutional and institutional rules of the country, cultural heritage (history, symbols, myths). As we have said, one of the factors of crisis in the idea of nation consists in the impact of erosive and conflicting elements on the cultural identity of a country. In reality, the entry into a country of other cultures represented by the coexistence of immigrants does not necessarily constitute the most significant external crisis factor. The multiplication of belonging is, in fact, a viable path both on a cultural and socio-political 
level, as various scientific and multicultural studies have shown. Instead, it is necessary to look with more concern at the smaller or greater capacity of the vehicle for transmitting national culture - and therefore of identity - presented by the central education system. If it is true, as Gellner maintains that it is culture, not the community that dictates the deepest norms (Gellner, 1983), it is necessary to look at the problems of access and use of the common culture by all citizens in the school as a premise and condition of a common identity and civic culture, able to integrate and include differences.

The objective of inclusion concerns the strengthening of the social bond at the level of citizens' equality. The "I next to us" is not an impossible ideal; on the contrary, it represents the necessary choice of an interdependent world, and for this reason education can act in this sense towards the strengthening of a civil society based on solidarity, favoring civic engagement and the inclusion of the other in the order of society.

The debate at socio-political level is open on the educational level, however, the question of citizenship questions the way in which the cultural difference is dealt with, especially in schools. In other words, one wonders if it is sufficient to have an intercultural education that is limited to forming respect for differences, or if it is not necessary to contribute to the consolidation of a new idea of enlarged citizenship, which addresses the problems deriving from cultural pluralism. In this second direction, it is necessary to think of an education for citizenship that knows how to avoid both the pitfalls of ethnocentric universalism and the dangers of relativism. At the center of a citizenship education project, along with the transmission of critical sense, rationality and the ability to manage complexity, we find above all the assumption of the problem of belonging, or rather of belonging, multiple, pluralistic, and not exclusive. The fundamental question in this regard, according to the philosopher Ricoeur (Ricoeur, 2005), concerns what belongings, legal systems and places of recognition of citizens, so that there is a political representation of these places of social and civil recognition. Recognition implies reciprocity and recomposition within all the different spheres of life, and not just one. In this regard, Jean Marc Ferry has called "recognition orders" the different places in which a person's identity is built: family, civil society, churches, state (Ferry, 2006). Education in social 
cohesion becomes, in today's society, an associated and complementary objective of autonomy and emancipation. Citizenship requires a dynamic work of memory and integration into a story; involves a project of inclusion of newcomers (in a generational, ethnic, social sense), bases the recognition of others in a mutual interdependence. Living today in a complex society implies the need to face the positive and dynamic tension between instances of universalism and the needs of particularism. Defensive closure in one's own cultural or ethnic identity risks limiting the resources of the person and of society itself if we do not learn about exchange and dialogue. A complex collective identity that goes beyond particularism means, in the life of a society, a resource and not a limit (Morin, 2015).

\section{Citizenship as sustainable deVelopment}

In the education of citizenship of the future citizen, education for the sustainable development of the environment in which they live is also important. The concept of active citizenship implies not only the citizen's participation in community life, but also respect for the surrounding environment. In the light of all that is happening in contemporary society, talking about active citizenship as a responsibility education is urgent and a priority. The modern a person aware that scientific discoveries, instead of being projected towards the good of humanity and the cosmos, can lead him to irreparably devastating results, rediscovers with a renewed wonder the mystery of his life and of creation and feels, in a whole way new, the responsibility to safeguard them. Numerous documents from the most recent ones such as Agenda 2030 to those a little more remote, such as the 1992 Kyoto Protocol on the reduction of greenhouse gas emissions (Francescano, Scanio, 2002, pp. 24-25), highlight the danger incumbent on a serious threat to our survival and that of the entire planet. The precautionary principle is applied in the political management of risk (linked to the lack of acceptable scientific conclusions) ${ }^{1}$, where there are threats of serious or irreversible damage to the environment, but also to the health of human beings, animals and plants, and recommends not to delay the adoption of effective measures to prevent such evils. In this sense the future citizen must rationally prevent harmful actions that can have serious consequences on the livability of the 
environment. In this sense, the hope for a future of liveability that does not damage human dignity and ensures respect for the environment in which we live can only be sustained by an ethical responsibility that involves the modus agendi and the life of each of us in the community. whole and of institutions (Zizioli, 2018, pp. 202 - 212).

This conception can be defined as a humanizing perspective because the intervention must take place in the context of future-oriented programs, in an appropriate time perspective, keeping in mind the current situation and trying to predict the drop in resources and the growth of human needs, also because development is essentially freedom and ethical responsibility, in the awareness that there is no growth without humanization and democracy (Sen, 2001 - Nussbaum 1997). The concept of perspective does not underestimate the role played by the natural environment, nor does it forget the reciprocity of man-environment relationships, highlighted by possibilism. However, while keeping these principles in mind, it proclaims the priority of the will and of the rationality with which a person must try to "act" on the environment and not simply "react" to it to protect and defend the right to life and improve by consequently the quality of life. This approach is suggested both by the awareness of the many imbalances that characterize our planet and by the intensification of relations with an increasingly wider environment.

The way in which human societies react to the environment and its resources depends on their ways of life. P. Vidal de la Blache does not conceive the environment that controls human activities, but as the whole in which heterogeneous beings cohabit in close and mutual relationship (Buttimer, 1971). A person over the centuries, through the accumulated work and the courage and decision of his enterprises, appears to be one of the most powerful modifying agents of the earth's surface. There is no energy that he does not use; there is no country that does not bear the traces of his intervention. He intervenes as an individual, but intervenes even more collectively, with the means of all his groups, from the minor to the major, from family groups to political ones (Febvre, 1966). A person cannot therefore be considered passively subject to the influences of the physical environment and controlled by natural forces. As Febvre states there are no necessities, but 
everywhere possibilities; and man, as the master of possibilities, is the judge of their use. Which, consequently, places a person in the first place, a person and no longer the earth, nor the influence of the climate, nor the determining conditions of the places (Febvre, 1924).

\section{References}

Baldacci M. (2014). Per un'idea di scuola. Istruzione, lavoro e democrazia. Milano: Franco Angeli. ISBN 9788820462772.

Baudrillard J. (1991). Citoyenneté et Urbanité. Paris: Ed. Esprit distribuito de Seuil. ISBN 9782909210032.

Buttimer A. (1971). Society and milieu in the French geographic tradition. Chicago: Rand Mc Nally \& Co.

Cadei L. - Deluigi R. - Pierre Pourtois J. (2016). Fare per, fare con, fare insieme. Progetti di cittadinanza tra scuola e famiglia. Parma: Edizioni Junior. ISBN 9788884347916.

Commissione delle Comunità Europee, Comunicazione della Commissione sul principio di precauzione, COM (2000) 1, del 2 febbraio 2000.

Francescano G. - Pecoraro Scanio A. (2002). Il principio di precauzione. Milano: Jaca Book. ISBN 9788816405929.

Febvre L.(1924). A geographical introduction to history. Londra: Routledge \& Kegan. ISBN 9780415487535.

Ferry J.M. (2006). Letica ricostruttiva. Milano: Medusa edizioni.

Fiorucci M. (2014). Educare alla cittadinanza globale: il contributo di Martha Nussbaum. In: G. Alessandrini (ed.), La ” Pedagogia “ di Martha Nussbaum, approccio alle capacità e sfide educative. Milano: Franco Angeli. ISBN 9788891706522.

Gellner E. (1992). Nazioni e nazionalismi. Roma:Editori Riuniti; ed. orig., (1983) Nations and Nationalism. Oxford: Blackwell. ISBN 9788835942191.

Indicazioni nazionali e nuovi scenari, 2018, D.M. 254/12, spostare „Indicazioni nazionali e nuovi scenari, 2018, DM 254/12" alla lettera I.

Morin E. (2015). Enseigner à vivre. Manifeste pour changer l'éducation. Paris: Actes Sud /Play Bac, tr.it., Insegnare a vivere. Manifesto per cambiare l'educazione, Milano: Raffaello Cortina. ISBN 9782330034320.

Mortari L. (2004). Educare alla cittadinanza partecipata. Milano: Mondadori. ISBN 9788861590977. 
Nussbaum M. C. (1997). Cultivating Humanity: A Classical Defense of Reform in Liberal Education, Massachusetts and London: Harvard University Press; tr.it., (1999). Coltivare l'umanità. I classici, il multiculturalismo, l'educazione contemporanea. Roma: Carocci. ISBN 9780674179493.

Nussbaum M. C. (2011). Not for Profit. Why Democracy Needs the Humanities, New Jersey: Princepton University Press, tr.it., Non per profitto. Perché le democrazie hanno bisogno di una cultura umanista. Bologna: Il Mulino. ISBN 9780691173320.

Pinto Minerva F. (2008). Lintercultura, Roma-Bari: Laterza.

Rapporto Eurydice 2012.

Reimers F. M. - Barzanò G. - Fisichella L. - Lissoni M. (2017) ( a cura di). Cittadinanza globale e sviluppo sostenibile. Milano: Pearson Academy.

Ricoeur, P. (2005). Percorsi del riconoscimento, Milano: Cortina Raffaello. ISBN 9788870789805.

Sen A. (2001). Lo sviluppo è libertà. Perché non cè crescita senza democrazia. Milano: Mondadori. ISBN 9788804491309.

Zizioli E. (2018). Quando ad accogliere non è la scuola: il ruolo delle public libraries nei territori di confine, in: Ulivieri, S. , Binanti L. , Colazzo S. , Piccinno M. (2018). Scuola Democrazia Educazione. Formare ad una nuova società della conoscenza e della solidarietà. Brescia- Lecce: Pensa Multimedia. ISBN 9788867605460.

Zizioli E. (2018a). Un racconto...è un diritto di tutti. Narrazione, comunità, contesti di crisi, in: Vaccarelli A. , Mariantoni S. (eds.), Individui, comunità e istituzioni in emergenza . Intervento psico-socio-pedagogico e lavoro di rete nelle situazioni di catastrofe. Milano: Franco Angeli. ISBN 9788891767967.

Zoletto D. (2017). Contesti eterogenei, in: Fiorucci M. , Pinto Minerva F. , Portera A. (eds), Gli alfabeti dell'intercultura. Pisa: ETS. ISBN 9788846749086.

\section{Endnotes}

${ }^{1}$ For example in situations where the scientific data are largely insufficient, in which it is not possible to adequately model reality, or where the cause / effect relationships are hypothesized but not demonstrated. According to the European Commission, which has dedicated an in-depth study to the precautionary principle, "when available data are inadequate or inconclusive, a prudent and precautionary strategy for the protection of the environment, health or safety could be to opt for for the most pessimistic hypothesis ". Commission of the European Communities, Communication from the Commission on the precautionary principle, COM (2000) 1, dated 2 February 2000, p.23. 